\title{
"The role of total quality management in enhancing the quality of private healthcare services"
}

\begin{tabular}{|c|c|}
\hline AUTHORS & $\begin{array}{l}\text { Mohannad Abu Daqar (D https://orcid.org/0000-0002-3549-6101 } \\
\text { R http://www.researcherid.com/rid/AAL-8483-2020 } \\
\text { Milan Constantinovits (D https://orcid.org/0000-0003-2593-0696 } \\
\text { R http://www.researcherid.com/rid/AAL-8598-2020 }\end{array}$ \\
\hline ARTICLE INFO & $\begin{array}{l}\text { Mohannad Abu Daqar and Milan Constantinovits (2020). The role of total quality } \\
\text { management in enhancing the quality of private healthcare services. Problems } \\
\text { and Perspectives in Management, 18(2), 64-78. doi:10.21511/ppm.18(2).2020.07 }\end{array}$ \\
\hline DOI & http://dx.doi.org/10.21511/ppm.18(2).2020.07 \\
\hline RELEASED ON & Monday, 27 April 2020 \\
\hline RECEIVED ON & Tuesday, 29 October 2019 \\
\hline ACCEPTED ON & Wednesday, 01 April 2020 \\
\hline LICENSE & $\begin{array}{l}(\mathrm{c}) \mathrm{EY} \\
\text { This work is licensed under a Creative Commons Attribution } 4.0 \text { International } \\
\text { License }\end{array}$ \\
\hline JOURNAL & "Problems and Perspectives in Management" \\
\hline ISSN PRINT & $1727-7051$ \\
\hline ISSN ONLINE & $1810-5467$ \\
\hline PUBLISHER & LLC "Consulting Publishing Company "Business Perspectives" \\
\hline FOUNDER & LLC "Consulting Publishing Company "Business Perspectives" \\
\hline
\end{tabular}

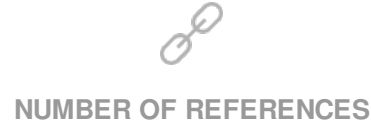

42

\section{NUMBER OF FIGURES}

2

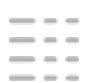

NUMBER OF TABLES

13

(C) The author(s) 2023. This publication is an open access article. 


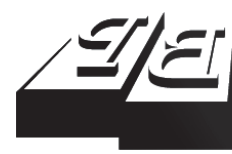

\section{BUSINESS PERSPECTIVES}

LLC "CPC "Business Perspectives" Hryhorii Skovoroda lane, 10, Sumy, 40022, Ukraine www.businessperspectives.org

Received on: $29^{\text {th }}$ of October, 2019 Accepted on: $1^{\text {st }}$ of April, 2020 Published on: $27^{\text {th }}$ of April, 2020

(C) Mohannad Abu Daqar, Milan Constantinovits, 2020

Mohannad Abu Daqar, Ph.D. Student Doctoral School of Management and Business Administration, Szent István University, Hungary. (Corresponding author)

Milan Constantinovits, Ph.D., Dr Habil., Associate Professor, Doctoral School of Management and Business Administration, Szent István University, Hungary.

\section{THE ROLE OF TOTAL QUALITY MANAGEMENT IN ENHANCING THE QUALITY OF PRIVATE HEALTHCARE SERVICES}

\begin{abstract}
The study aims to explore the role of total quality management (TQM) in enhancing the service quality of the private healthcare sector in the Northern Area of West Bank Palestine. The study involves a questionnaire-based survey, private hospitals, and healthcare centers selected in North West Bank. The administrative employees are the population of the study, 200 employees were selected via stratified sampling method. By using the Structural Equation Modeling (SEM), the findings show that all TQM factors are positively and directly related to each other in the private healthcare sector. There is a positive and direct relationship between four TQM factors (customer satisfaction, employee involvement, continual improvements, and top management commitment) and service quality, while there is a negative direct relationship between processes and service quality. TQM factors (customer satisfaction, employee involvement, continual improvements, processes, and top management commitment) explained $95 \%$ of the variance in healthcare service quality $\left(\mathrm{R}^{2}=0.950, \mathrm{P}<0.05\right)$. Continual improvements is the main pillar in TQM application in healthcare sector, and it is highly associated with the private healthcare processes $\left(\mathrm{R}^{2}=0.907, \mathrm{P}<0.01\right)$, while top management commitment is the most significant factor in improving the service quality. Full understanding and commitment by the managers across all levels and activating the effective communication between employees at all levels in the organization are the key factors of a successful TQM implementation; it helps in strengthening the teamwork efficiency. Top management is required to avoid the monotonic managerial practices, especially in the organizational processes, as it has a negative impact on the private healthcare service quality.
\end{abstract}

\section{Keywords} quality, total quality management, primary healthcare, secondary healthcare, customer satisfaction

\section{JEL Classification I11, M10}

\section{INTRODUCTION}

As long as the healthcare sector is considered the main pillar of the country, enhancing the quality of the provided services to patients is the main concern of the decision-makers and the top management of the healthcare organizations and centers due to the massive competition across this sector in Palestine. The significance of this study comes from the current skills gap in the Palestinian healthcare sector, which suffers from the deficiency of skilled professionals in this sector to manage these organizations and centers efficiently to enhance the healthcare services quality at the end. This gap covered both the medi$\mathrm{cal}$ and the administrative employees. The researcher will focus on the administrative employees in this sector (Abdullah, 2018).

Abdullah's (2018) study is the most recent in Palestine investigating the skills deficiency across the healthcare sector. The notable results about this study are classifying the skills deficiency for both the managerial and administrative employees. The root causes of skills gap and 
deficiency for managerial positions are: top management skills, financial skills, leadership, communication, politely treating patients, and time commitment, whereas, for mid-level positions, they are: using the new devices, dealing with patients, leadership, work loyalty, teamwork, communication, training efficiency, and handling responsibilities.

The researchers took the initiative to investigate the role of the management practices to enhance the service quality in Palestine, the reason behind choosing the private sector is that the government healthcare sector has a centralized policy in their managerial practices. So, the researcher will apply the TQM principle to measure its influence on healthcare service quality. TQM was used as a managerial approach to measuring different aspects such as the management commitment and the employee involvement in the organization, so that this study will adopt this approach.

TQM concept was defined as an administration concept, which allows every contributor involved in the corporation to enhance and improve the corporation quality and the performance as well to instill and establish the quality pillars and concepts (Talib, Rahman, \& Azam, 2010). Healthcare services comprise a wide variety of important quality aspects. In the healthcare services case, doctors, nursing homes, hospitals, clinics are considered as sellers since all of them offer and provide healthcare services for sale based on specific prices. On the other hand, the buyer is only the patient or client who will buy the offered healthcare services at a stipulated price. It also includes the performance quality, which is closely related and directly connected to healthcare, as housing, food, security, attitude of employees, safety, and other factors arise that are in connection with nursing homes and hospitals (Patel, 2015).

This study aims to explore the influence of TQM practices in the private healthcare sector in Palestine to improve the quality of care in this sector and to determine if there is any relationship between TQM and the quality of service provided by the healthcare sector.

\section{LITERATURE REVIEW}

\subsection{Definition of key terms}

Quality: Is a perception based on the individual value system for the person. It heavily depends on the expectations for each individual, culture, and life experiences (Mi. Halis, Twati, \& Mu. Halis, 2017).

Total quality management: Defines the culture, organization, and attitude of any company or association, which tries to offer these consumers with the required products and services that meet and fulfill their need (Mi. Halis, Twati, \& Mu. Halis, 2017).

Primary healthcare (PHC): Refers to beliefs and processes related to ways that healthcare is constructed. PHC comprises disease prevention, health promotion, primary care, community development, and population health within a holistic framework, which aims to provide essential healthcare for the community (WHO, 2004).
Secondary healthcare (SHC): Health professionals and other medical specialists who do not have initial contact with the patients, the SHV infrastructure at the urban hospitals and district hospitals are taking care of the PHC needs of the city/ town citizens based on which they are located in these places (WHO, 2004).

Recently, healthcare sector globally is witnessing many successive variables, while the desire of healthcare development requires continual improvement and development in the quality management system to fast-track the pace of the new developments and to optimally manage the resources to improve the service quality and care to satisfy the customers and quickly respond to their expectations and aspiration in the right manner.

TQM term describes "the attitude, culture, and organization of any association or company that attempts to offer consumers with services and products which serve their needs" (Mi. Halis, Twati, \& Mu. Halis, 2017). This culture requires a certain and specific amount of quality to be applied and 
embedded in all the operations phases. Proper processes will be done at the first try, combined side by side with processes, which are responsible for eliminating operations defects.

TQM is a system that makes all the administrators and clinicians responsible for the quality of their healthcare organization. Systems in total quality management have been established to prevent most of the related administrative and clinical problems, increase patient satisfaction, improve the organizational processes continuously, and provide the healthcare services in the form of good, or better (Talib, Rahman, \& Azam, 2010). TQM, as a universal management concept, includes all of the following concepts: employee participation, error prevention, customer focus, teamwork, leadership systemization, and the continuous improvements of quality. These concepts can be transferred and relocated to any business setting. Quality is the fundamental and the basic measurement tool of TQM, where continuous improvement is considered as the philosophy and on the part of employee's involvement is considered as the approach. Thus, in healthcare, TQM applications can be measured without paying much effort and the need to obtain deep and specific knowledge about the unique circumstances of the healthcare sector (Mohammad, 2014). TQM is defined in Davies' study (2003) as a management attitude that deals with work processes and people; it aims to enhance customer satisfaction and organizational performance.

Perrott (2002) refers to quality through achieving the maximum patient's satisfaction toward the provided services, and to enhance the organization's financial performance. One more definition related to US theories stressed that TQM is a significant management method (Dagger, Sweeney, \& Johnson, 2007). Al-Shdaifat (2015) illustrates that TQM is a continuous quality improvement, which combines two concepts: management method and philosophy.

For a company to deliver its offers and to reach its customers, it is obvious that it needs services. The forms of these services depend on the product types offered by the company, and usually, it differs among various organizations. RamseookMunhurrun, Lukea-Bhiwajee, and Naidoo (2015) defined service as a whole package consisting of all the activities that are significant to achieve customer satisfaction. Though, for J.-S. Lim, K.-S. Lim, Heinrichs, Al-Aali, Aamir, and Qureshi (2018), service quality defined as the source of the organization's competitive advantage for the service-oriented sector. According to J.-S. Lim, K.-S. Lim, Heinrichs, Al-Aali, Aamir, and Qureshi (2018), service is well-defined as a set of characteristics that achieve customer's requirements and satisfaction through meeting their expectations to build strong partnerships with them. Whereas, according to Parasuraman, Zeithaml, and Berry (1988), service quality is expressed in a meaningful way, which is the customer's expectations. According to these authors, customers always have personal expectations for different companies; they compare personal expectations with the perceived service quality of the company. If this quality meets or exceeds customers' expectations, it will lead to a good feeling and they will be happy. On the contrary, if perceived quality is lower than customers' expectations, then customers will be disappointed.

It is considered that service is characterized with quality when it satisfies customer's demands and needs, and provides a consistent service, which meets or exceeds customer's expectations. The service quality common factors are as follows:

- Process quality: related to processes and quality of production methods and providing services to customers.

- Product quality: the evaluation after providing the service. Actually, the customer gets a product from the organization.

- Physical quality: refers to goods or services with acceptable performance over a reasonable length of time (Nzioka \& Njuguna, 2017).

- Interactive quality: defined as relations and interactions between the firm customers and the service providers.

- Organization quality: refers to the organization's image in the customers' minds and total perception of the organization. Typically, the quality of an organization is intangible (AlRefaie, Ghnaimat, \& Ko, 2011). 
Table 1. Perceived service quality dimensions

Source: Parasuraman, Zeithaml, and Berry (1988).

\begin{tabular}{|c|c|}
\hline Dimensions & $\begin{array}{ll}\text { Explanation } \\
\end{array}$ \\
\hline Tangibles & Physical facilities, equipment, and appearance of personnel \\
\hline Reliability & Ability to perform the promised service dependably and accurately \\
\hline Responsiveness & Willingness to help customers and provide prompt service \\
\hline Assurance & Knowledge and courtesy of employees and their ability to inspire trust and confidence \\
\hline Empathy & Caring, individualized attention the firm provides its customers \\
\hline
\end{tabular}

Service quality management encompasses the quality management application of practices in all the organizational aspects, which includes customers, suppliers, and integration between them, as it is the key to business processes (Masrurul, 2018). Behara, Fisher, and Lemmink (2016) talked about business performance and the practices of quality management. Based on this study, the author selected seven main practices of service quality management: incentives and recognition, customer focus, top management support, continual improvements, employee involvement, innovation, system process, and process management.

Gorji (2017) found that HR management strategies have a significant positive effect on organizational performance. To keep the competitiveness, the organization should manage and train its staff to improve their abilities and skills, which is responsible for increasing and improving organizational performance. The organization's employees might acquire new skills and knowledge through their participation in service quality management. Through this participation, it leads to long-lasting changes in behavior in the organization, which enhances and improves quality. Brysland and Curry (2015) emphasize that an organization should step forward to tailor its products to meet the custom- ers' needs instead of paying much effort in studying customer segments.

According to Sofijanova and Zabijakin-Chatleska (2013), continual improvements are related to both incremental and flourishing improvements in organizational performance. The most important parts of the service are innovation and continuous improvement. It means to keep the pace of improvements and processes developments to find out innovative methods in the process cycle to convert inputs into useful outputs.

Parasuraman, Zeithaml, and Berry (1988) defined five dimensions of perceived service quality (tangibles, empathy, assurance reliability, and responsiveness). These dimensions link specific service features to customers' expectations as listed in Table 1.

The authors used the restructured model of service quality from Marshall and Murdoch (2001). This model has been derived from Parasuraman model (Parasuraman, Zeithaml, \& Berry, 1988). The authors adopted this model because it reflects the intended objectives behind measuring the service quality from the employees' point of view; it helps in avoiding the bias when employees respond to

Table 2. Restructured model of service quality

Source: Marshall and Murdoch (2001).

\begin{tabular}{|c|c|c|}
\hline $\begin{array}{l}\text { The original model (Parasuraman, } \\
\text { Zeithaml, \& Berry, 1988) }\end{array}$ & $\begin{array}{l}\text { Restructured model } \\
\text { (Marshall \& Murdoch, 2001) }\end{array}$ & Items description \\
\hline Tangibility & Tangibility & Physical aspects of what is provided to patients \\
\hline Reliability & Reliability & Ability to fulfill what was promised accurately to patients \\
\hline Responsiveness & Responsiveness & $\begin{array}{l}\text { Ability to attend to the patients and provide the service } \\
\text { promptly, capturing the notion of flexibility and ability to } \\
\text { adapt to the needs of the service patients }\end{array}$ \\
\hline $\begin{array}{l}\text { Competency, courtesy, credibility, } \\
\text { safety }\end{array}$ & Assurance & $\begin{array}{l}\text { Competency and courtesy extended to the patients and } \\
\text { the security provided by the operations }\end{array}$ \\
\hline $\begin{array}{l}\text { Access, communication, } \\
\text { comprehension of the user }\end{array}$ & Empathy & Individualized attention to patients \\
\hline
\end{tabular}


the service quality items that touch their institute service quality. The new items assist employees in expressing their views about service quality in a way that captures the big image of service quality. Table 2 shows the restructured model of service quality used in this study compared with the original Parasuraman model.

Management commitment is the main strategic issue, which is responsible for the company's quality development. It needs their contributions and support, allocating acceptable and suitable resources to enhance the company training activities, which leads to better quality measurement, improving benchmarking and customer satisfaction. Ramseook-Munhurrun, Munhurrun, and Panchoo (2011). Nabitz and Walburg (2016) recommended and advised top management to identify the organization's quality improvement areas, such as hospital quality services and teamwork, to achieve continual total quality management implementation. There are normative pressures at the hospital directors to adopt and implement innovative and creative management practices like total quality management.

Employee involvement is a crucial pillar of TQM. TQM needs the management commitment to ensure that employees are completely engaged in quality work culture and create a healthy brand image through providing and offering high service quality to the customers (Patel, 2015). By increasing the employees' participation in the organization's overall quality strategy, it will increase the transmission of knowledge and information, and will help the organization to resolve problems (James, 2017). From the employees' point of view, the main aim of applying such a TQM system is increasing the work responsibilities.

TQM aims to ensure that customer satisfaction is the main priority of the organization. With great efforts that the organization dedicates to meet or exceed its customers' expectations in all transactions, TQM requires a robust relationship with customers to determine their needs and requirements. Therefore, it requires higher customer involvement in the development and product design process. TQM aims to provide a success template for organizations through customer satisfaction concept (James, 2017). Customer focus is a con- cept that hospitals used to meet the customers' needs and their long-term expectations.

Teamwork is considered a critical and significant dimension in TQM, as teamwork is crucial in applying process management functions and its improvements, which is mostly used in healthcare sector. To achieve higher cooperation, it requires all correlated departments to cooperate with each other to achieve work goals (Scholtes, 2015). According to Neetha, Srinivas, Ramachandra, and Manjunatha (2016), teamwork is crucial to avoid sectionalism in work and to strengthen the cooperation between all departments to improve the organization's quality. The critical part of the TQM system is creating an environment under the concept of "all one team" (Taylor \& Wright, 2017). Besides, the author adds that every employee in the organization should work together with other employees to improve the work processes to accomplish them effectively.

TQM is placed to effectively manage the organizational processes and to keep the continual customer's satisfaction. The organization improves its processes by reducing the variation sources, which exist in these processes. TQM environment requires obtaining extra capabilities to enhance the organizational processes, which needs well-designed and well-defined processes to achieve the organizational performance and quality requirements (Al-Omar, 2002). It is recommended that hospitals need to focus its activities on integrating various processes through many different levels, such as human resource management, quality management, etc. to meet and exceed customers' expectations, which leads to organizational excellence.

Continual improvements is a key concept and one of the most powerful concepts in TQM, which is related to non-stop improvement to meet the internal and external customer needs (Ozdal \& Oyebamiji, 2018). Continual improvement requires managing by facts as taken for granted concept adopted by all employees and, on the other hand, the employee's commitment and their emphasis on teamwork to endorse the bottom-up approach to improve quality (Milakovich, 1991). Continual improvement is one of the most powerful improvement philosophies that promote success and reduce failures. 
The researches reflected the previous research's findings in this study as the guide to develop the current model of the study. All these studies focused on assessing the service quality of the healthcare sector in Palestine. Al-Adham (2004) constructed a TQM model to assess the quality of healthcare services. This research aims to reveal good managerial practices in managing hospitals. The author used the following main dimensions of TQM: top management role (their intervention in processes), patient satisfaction, continuous improvement, leadership development. The lack of operational systems was one of the main findings of this study. Patient satisfaction has a direct relationship with processes. TQM represents a good model in assessing the organization's practices in maintaining the quality of the healthcare services in the Palestinian context through their commitment to continual improvements.

Narallah (2009) examined the implementation level of TQM success factors measures in the Palestinian healthcare sectors, governmental, and non-governmental hospitals. The author used different dimensions to assess TQM: top management commitment and leadership, process management, patient focus, employee focus, and continuous improvements. The findings showed a high implementation of these TQM dimensions in these hospitals, and it helps in maintaining the ISO standards for the healthcare sectors, especially for hospitals. The study revealed the aspects of TQM that healthcare sector needs to focus on to achieve higher TQM implementation and more customers' satisfaction, parts of these aspects such as top management and leadership, employee focus, hospital information systems, and governance and social responsibility.

Nasser, Khraim, and Mousa (2016) conducted a study in North West Bank-Palestine to measure the TQM implementation in the governmental hospitals. They used the following TQM model to assess the hospitals' commitment in implementing the TQM factors: top management commitment, customer focus, employee involvement, training, continual improvements, leadership. The authors found a lower awareness level among the respondents about three different factors: employee involvement (42.9\%), patent focus (33.9\%), and continual improvements (42.9\%).
Regardless of the lack of studies that linked the TQM implementation with the quality of healthcare services in Palestine, the researchers adopt the common TQM factors used by other researchers who performed similar studies in the same context.

\subsection{Study hypotheses}

This study consists of two main hypotheses:

H01: TQM factors do not directly relate to each other in the private healthcare sector in North West Bank Palestine.

Ha1: TQM factors directly relate to each other in the private healthcare sector in North West Bank Palestine.

H02: TQM factors do not influence service quality in the private healthcare sector in North West Bank Palestine.

Ha2: TQM factors influence service quality in the private healthcare sector in North West Bank Palestine.

\section{DATA AND METHODS}

\subsection{Data collection}

The researcher used both secondary and primary sources. Primary data were collected using a questionnaire consisting of 7 parts developed to achieve the main objectives of the study. The parts of this questionnaire are as follows: total quality management (TQM) factors: top management commitment, employee involvement, customer satisfaction, teamwork, processes, and continual improvements. These factors represent the independent variable, while the dependent variable is the service quality. Secondary data sources were mainly covered by reviewing previous literature, journals, books, and websites to help to prepare the theoretical framework.

\subsection{Reliability and validity}

To extract the questionnaire reliability coefficient, the authors used Cronbach's alpha equation to determine the internal consistency among the 
Table 3. Reliability test

Source: Researchers.

\begin{tabular}{|c|c|c|c|}
\hline Variable & No. of items & Cronbach's alpha & Result/Pass \\
\hline \multicolumn{4}{|c|}{ Independent variable (TQM) } \\
\hline Top management commitment & 5 & 0.787 & Yes \\
\hline Employee involvement & 3 & 0.764 & Yes \\
\hline Customer satisfaction & 5 & 0.706 & Yes \\
\hline Teamwork & 2 & 0.774 & Yes \\
\hline Processes & 2 & 0.716 & Yes \\
\hline Continual improvements & 5 & 0.755 & Yes \\
\hline \multicolumn{4}{|c|}{ Dependent variable (service quality) } \\
\hline Tangible & 3 & 0.762 & Yes \\
\hline Reliability & 5 & 0.769 & Yes \\
\hline Responsiveness & 4 & 0.708 & Yes \\
\hline Assurance & 4 & 0.74 & Yes \\
\hline Empathy & 5 & 0.763 & Yes \\
\hline
\end{tabular}

set of questionnaire dimensions. The calculated Cronbach's alpha for all variables is above 0.70 . It means that the reliability values for the study variables are accepted (Travakol \& Dennick, 2011).

The authors used the confirmatory factor analysis to test the study variables; convergent validity was used for this purpose. Instrument validity means the degree that the study model is a good fit with survey data, which is including convergent validity test. "The convergent validity reflects the correlation degree of multiple indicators for a variable, which is measured by the average variance extracted (AVE) of the latent variable, the $\mathrm{CR}$, and the loading of corresponding measurable variables" (Ruvio, Shoham, \& Brenčič, 2008; Chin, 1998; Bagozzi, Yi, \& Phillips, 1991). AVE of sample must be greater than 0.5 , while the loadings of variables must be greater than 0.7. All evidence in
Table 4 supports the convergent validity of all variables. As listed in Table 4, AVE was greater than 0.5 for all study variables and CR as well larger than 0.7 , so validity is granted in this study.

\subsection{Population and sampling method}

The researcher targeted private healthcare organizations such as hospitals and healthcare centers in the Northern Area of West Bank Palestine, 3 private hospitals and 11 private healthcare centers (secondary healthcare centers) that were selected for the study. There are 17 private hospitals in the West Bank Area (MOH, 2019); North West Bank has 3 hospitals. The targeted population is the administrative employees working in the private healthcare sector in North West Bank. The total employees in West Bank are approximately 2,100 employees, while in North West Bank, there are

Table 4. Validity test

\begin{tabular}{|c|c|c|c|c|}
\hline Variable & Items & AVE & CR & Result/Pass \\
\hline \multicolumn{5}{|c|}{ Independent variable } \\
\hline Top management commitment & 5 & 0.545 & 0.803 & Yes \\
\hline Employee involvement & 3 & 0.529 & 0.769 & Yes \\
\hline Customer satisfaction & 5 & 0.535 & 0.793 & Yes \\
\hline Teamwork & 2 & 0.544 & 0.761 & Yes \\
\hline Processes & 2 & 0.537 & 0.754 & Yes \\
\hline Continual improvements & 5 & 0.505 & 0.835 & Yes \\
\hline \multicolumn{5}{|c|}{ Dependent variable } \\
\hline Tangible & 3 & 0.674 & 0.861 & Yes \\
\hline Reliability & 5 & 0.576 & 0.872 & Yes \\
\hline Responsiveness & 4 & 0.534 & 0.820 & Yes \\
\hline Assurance & 4 & 0.635 & 0.874 & Yes \\
\hline Empathy & 5 & 0.549 & 0.829 & Yes \\
\hline
\end{tabular}


Table 5. Study variables

Source: Researchers.

\begin{tabular}{|c|c|c|}
\hline Variable & Type & Sub-dimensions \\
\hline \multirow{6}{*}{ Total quality management (TQM) } & \multirow{6}{*}{ Independent } & Top management commitment (TMC) \\
\hline & & Employee involvement (EI) \\
\hline & & Customer satisfaction (CS) \\
\hline & & Teamwork (TW) \\
\hline & & Processes (PR) \\
\hline & & Continual improvements $(\mathrm{Cl})$ \\
\hline Service quality (SQ) & Dependent & - \\
\hline
\end{tabular}

approximately 735 employees. The authors targeted the cities in the Northern Area of West Bank, and four cities have been selected for this purpose out of 11 cities. The authors covered the private hospitals in these four cities, along with choosing the biggest private healthcare centers per each city. The criteria for this selection were based on the number of administrative employees working in these centers. The study targeted the private healthcare sector because the government healthcare sector has a centralized policy from the government. The targeted group was the administrative employees of these organizations and centers, as they are involved in the TQM system, and they are part of the quality system. The study aims to measure the TQM from the employees' point of view. The authors used the stratified sampling method in distributing the study instrument for the targeted respondents. 20 surveys were distributed for each targeted place, 280 surveys have been distributed, and the retrieved surveys were 200 .

\subsection{The study model}

The main aim of the authors in this study is to explore the role of TQM factors in service quality in the healthcare sector in Palestine. Healthcare sector needs to enhance its service quality through its best practices to provide the desired service for its customers, which comes from their TQM best practices to deliver the expected services that are aligned with the customers' needs and expectations. The conceptual framework was developed by the authors based on this framework. TQM factors are the main key component of TQM. Table 5 shows the study independent and dependent variables: TQM factors and service quality, respectively. Tables 6 and 7 show the scale per each variable used in the study model. Figure 1 shows the conceptual framework.
Table 6 explains the scale for six dimensions of the independent variable, which is the TQM.

Table 6. TQM scale

Source: Ramseook-Munhurrun, Munhurrun, and Panchoo (2011), Mi. Halis, Twati, and Mu. Halis (2017), Awuor and Kinuthia (2013).

\begin{tabular}{|c|c|}
\hline Variable & Items \\
\hline TMC & $\begin{array}{l}\text { - Quality considered as main strategic priority by top } \\
\text { management } \\
\text { - Top management and major department heads are } \\
\text { hired based on quality performance } \\
\text { - Top management and departments managers are } \\
\text { promoted \& evaluated based on quality standard } \\
\text { outputs } \\
\text { - Management interested in employing high } \\
\text { competence employees } \\
\text { - Commitment of top management to obtain quality } \\
\text { training }\end{array}$ \\
\hline El & $\begin{array}{l}\text { - Employees encouraged to be involved in quality } \\
\text { decision-making } \\
\text { - Employees often work in teams with other } \\
\text { members from different departments } \\
\text { - Employees committed to the success of } \\
\text { organization }\end{array}$ \\
\hline $\mathrm{CS}$ & $\begin{array}{l}\text { - Healthcare organization interested in knowing } \\
\text { patients' needs and expectations } \\
\text { - Organization uses patients' requirements and } \\
\text { expectations as the base for quality } \\
\text { - Organization makes quick responses upon patients' } \\
\text { inquiries } \\
\text { - Organizational processes designed/improved based } \\
\text { on patients' requirements } \\
\text { - Organization invents new service delivery ways to } \\
\text { satisfy patients }\end{array}$ \\
\hline TW & $\begin{array}{l}\text { - Employees work closely as a team to coordinate } \\
\text { work and enhance quality } \\
\text { - Team recognition rather than individual recognition } \\
\text { by management }\end{array}$ \\
\hline PR & $\begin{array}{l}\text { - Organization has a program in finding costs and } \\
\text { wasted time in all its internal processes } \\
\text { - All organization processes were designed to meet } \\
\text { the quality standards }\end{array}$ \\
\hline $\mathrm{Cl}$ & $\begin{array}{l}\text { - Top management supports long-term quality } \\
\text { improvements processes } \\
\text { - Top management provides essential resources for } \\
\text { continual improvements } \\
\text { - Continual improvements of processes handled by } \\
\text { teamwork } \\
\text { - Employees encouraged to experience new } \\
\text { approaches } \\
\text { - Explicit works policies were existing to assist } \\
\text { employees to improve processes continually }\end{array}$ \\
\hline
\end{tabular}


Table 7 shows the scale used for the dependent variable.

Table 7. SQ scale

Source: Marshall and Murdoch (2001), Pekkaya, Imamoğlu, and Koca (2017).

\begin{tabular}{|c|c|}
\hline Tangible & $\begin{array}{l}\text { - Transportation facilities are good for patients } \\
\text { - Physical conditions are appealing for patients } \\
\text { - Modern medical equipment is available in } \\
\text { hospital }\end{array}$ \\
\hline Reliability & $\begin{array}{l}\text { - Healthcare services are performed in time } \\
\text { - Procedures practiced fits the instructions } \\
\text { - Hospital employees are confident } \\
\text { - Patients records are kept accurately } \\
\text { - Patient confidentiality is protected }\end{array}$ \\
\hline Responsiveness & $\begin{array}{l}\text { - Services are speedily carried out } \\
\text { - Service time is declared exactly } \\
\text { - Employees are willing to service } \\
\text { - Employees are willing to protect patients' } \\
\text { rights }\end{array}$ \\
\hline Assurance & $\begin{array}{l}\text { - Patients reassured } \\
\text { - Patients treated politely } \\
\text { - Patients get enough information } \\
\text { - Answers are satisfying for patients }\end{array}$ \\
\hline Empathy & $\begin{array}{l}\text { - Working schedule fits the patients' will } \\
\text { - Patients get individual care } \\
\text { - Consultancy is received as expected } \\
\text { - Patients' complaints seriously cared } \\
\text { - Understanding to individual requests }\end{array}$ \\
\hline
\end{tabular}

\section{RESULTS}

\subsection{Descriptive statistics of respondents}

The respondents' data were statistically analyzed using SPSS v20. The descriptive analysis for 200 respondents of this study shows the demographic characteristics based on their gender, age, education, years of experience, and monthly income, as shown in Table 8. Based on gender distribution, male respondents were the majority of respondents (51.5\%), as for age distribution, respondents aged $26-35$ years old were (40.5\%), they are the highest proportion. Moreover, bachelor respondents were the highest proportion among the other education categories. Based on years of experience, both respondents with 4-7 and 8-11 years of experience showed approximately a similar proportion with $39 \%$ and $36 \%$, respectively. Besides, the respondents with income between USD 1,001 and 2,000 were the majority of respondents, with $82 \%$ of all the respondents of the study.

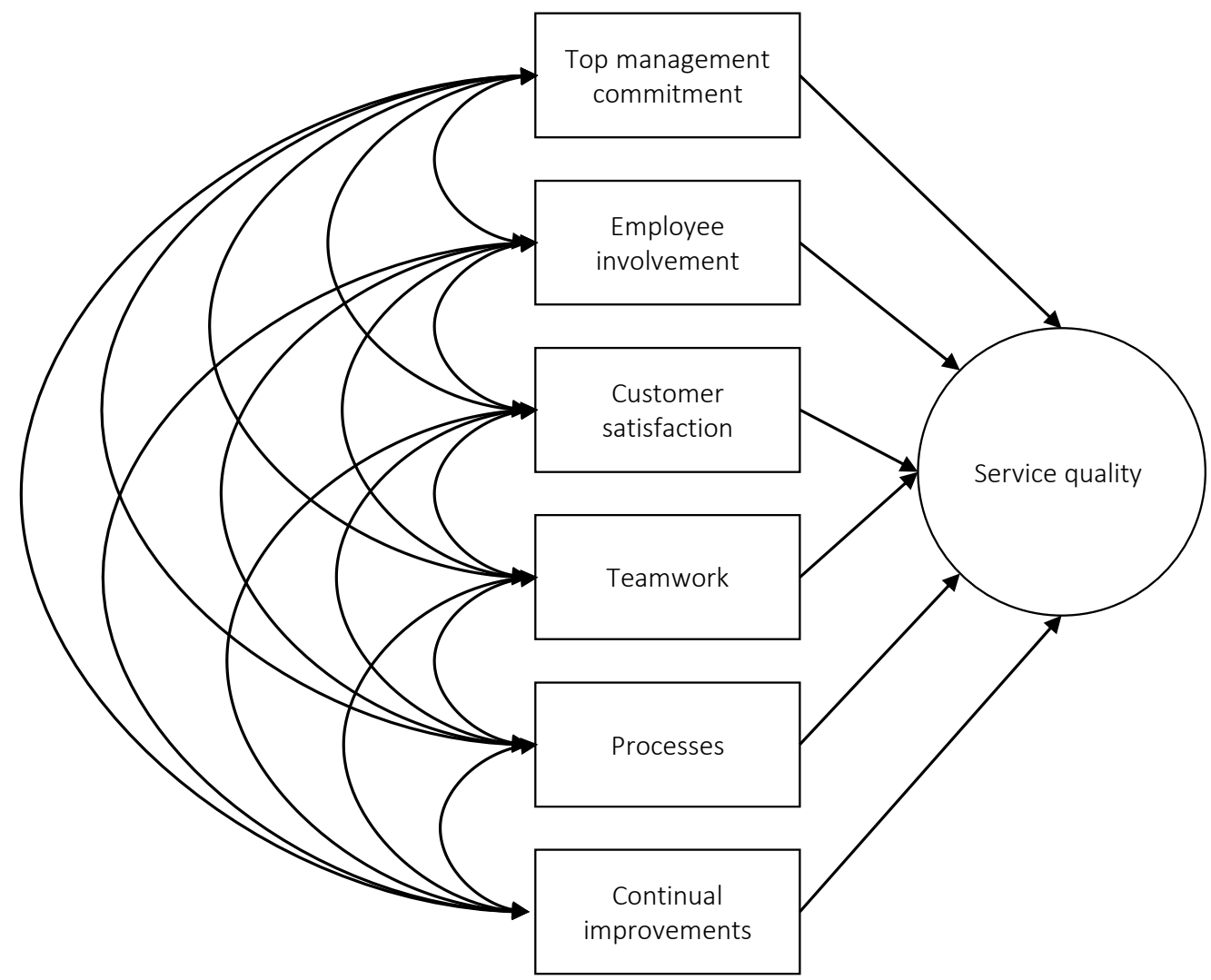

Figure 1. Conceptual framework 
Table 8. Respondents' characteristics

Source: Researchers.

\begin{tabular}{|c|c|c|c|}
\hline \multicolumn{2}{|c|}{$\begin{array}{c}\text { Demographic variable } \\
\text { and category }\end{array}$} & \multirow{2}{*}{\begin{tabular}{|c} 
Frequency \\
103
\end{tabular}} & \multirow{2}{*}{$\begin{array}{l}\text { Percentage } \\
51.5 \%\end{array}$} \\
\hline Gender & Male & & \\
\hline Gender & Female & 97 & $48.5 \%$ \\
\hline \multirow{4}{*}{ Age } & $18-25$ & 39 & $19.5 \%$ \\
\hline & $26-35$ & 81 & $40.5 \%$ \\
\hline & $36-45$ & 59 & $29.5 \%$ \\
\hline & $>45$ & 21 & $10.5 \%$ \\
\hline \multirow{4}{*}{ Education } & Less than diploma & 0 & $0.0 \%$ \\
\hline & Diploma & 14 & $7.0 \%$ \\
\hline & Bachelor & 160 & $80.0 \%$ \\
\hline & Master or higher & 26 & $13.0 \%$ \\
\hline \multirow{4}{*}{$\begin{array}{l}\text { Years of } \\
\text { experience }\end{array}$} & $0-3$ & 21 & $10.5 \%$ \\
\hline & $4-7$ & 78 & $39.0 \%$ \\
\hline & $8-11$ & 72 & $36.0 \%$ \\
\hline & $>11$ & 29 & $14.5 \%$ \\
\hline \multirow{4}{*}{ Income } & Less than 500 USD & 7 & $3.5 \%$ \\
\hline & $500-1,000 \$$ & 20 & $10.0 \%$ \\
\hline & $1,001-2,000 \$$ & 164 & $82.0 \%$ \\
\hline & $>2,000$ USD & 9 & $4.5 \%$ \\
\hline
\end{tabular}

\subsection{Hypotheses testing}

The researchers used the Structural Equation Modeling (SEM) by using SPSS AMOS v.24 as the main statistical tool in this study. SEM was used to investigate the relations of the variables using the covariance matrix of the model variables. Moreover, this type of statistics is important to explore the correlations between the study variables and to assess the impact of the independent variable on the dependent variable. Furthermore, through the calculation of the estimates, the researchers will reveal the econometric equation. Figure 2 shows the conceptual model using SEM analysis.

From Figure 2, the researchers constructed the required analysis and calculations, which are used to answer the study hypotheses. Covariances, correlations, and regressions weights were used for this purpose based on the statistical analysis mentioned in the following tables.

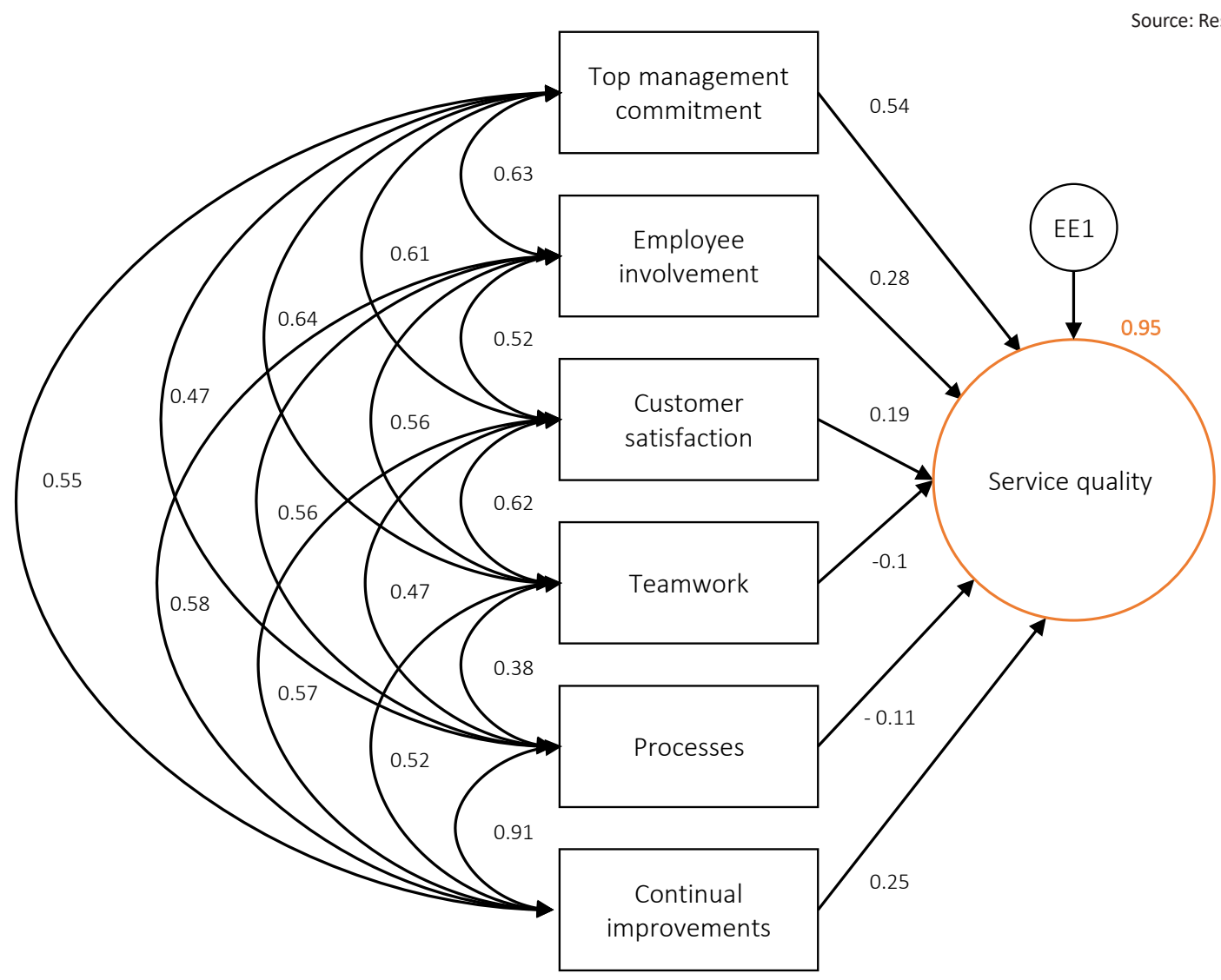

Note: 0.95 comes from Table 12 (squared multiple correlation) and the other variables come from Table 10 (Correlations), $(0.54,0.28,0.19,-0.1,-0.11,0.25)$ comes from Table 13.

Figure 2. Conceptual model (SEM) 
Table 9. Covariances

\begin{tabular}{|c|c|c|c|c|c|c|}
\hline \multirow{2}{*}{\multicolumn{3}{|c|}{ Path coefficients }} & \multicolumn{4}{|c|}{ Source: Researche } \\
\hline & & & Estimate & S.E. & C.R. & $\mathbf{P}$ \\
\hline $\mathrm{Cl}$ & $\leftrightarrow$ & TMC & 0.266 & 0.056 & 4.791 & $* * *$ \\
\hline $\mathrm{El}$ & $\leftrightarrow$ & TMC & 0.381 & 0.071 & 5.359 & $* * *$ \\
\hline CS & $\leftrightarrow$ & TMC & 0.28 & 0.054 & 5.202 & $* * *$ \\
\hline TW & $\leftrightarrow$ & TMC & 0.332 & 0.061 & 5.409 & $* * *$ \\
\hline PR & $\leftrightarrow$ & TMC & 0.255 & 0.06 & 4.265 & $* * *$ \\
\hline CS & $\leftrightarrow$ & El & 0.26 & 0.056 & 4.605 & $* * *$ \\
\hline TW & $\leftrightarrow$ & $\mathrm{El}$ & 0.316 & 0.064 & 4.903 & $* * *$ \\
\hline El & $\leftrightarrow$ & PR & 0.332 & 0.068 & 4.914 & $* * *$ \\
\hline $\mathrm{El}$ & $\leftrightarrow$ & $\mathrm{Cl}$ & 0.306 & 0.061 & 5 & $* * *$ \\
\hline CS & $\leftrightarrow$ & TW & 0.268 & 0.051 & 5.276 & $* * *$ \\
\hline $\mathrm{CS}$ & $\leftrightarrow$ & PR & 0.21 & 0.05 & 4.226 & $* * *$ \\
\hline $\mathrm{CS}$ & $\leftrightarrow$ & $\mathrm{Cl}$ & 0.231 & 0.047 & 4.942 & $* * *$ \\
\hline TW & $\leftrightarrow$ & PR & 0.192 & 0.054 & 3.545 & $* * *$ \\
\hline TW & $\leftrightarrow$ & $\mathrm{Cl}$ & 0.236 & 0.051 & 4.599 & $* * *$ \\
\hline $\mathrm{Cl}$ & $\leftrightarrow$ & PR & 0.433 & 0.065 & 6.716 & $* * *$ \\
\hline
\end{tabular}

Note: $* * *$ - significantly different from zero at the 0.001 level (two-tailed).

Table 10. Correlations

\begin{tabular}{|c|c|c|c|}
\hline \multicolumn{3}{|c|}{ Path coefficients } & \multirow{2}{*}{$\frac{\text { Estimate }}{0.546}$} \\
\hline $\mathrm{Cl}$ & $\leftrightarrow$ & TMC & \\
\hline $\mathrm{El}$ & $\leftrightarrow$ & TMC & 0.635 \\
\hline CS & $\leftrightarrow$ & TMC & 0.609 \\
\hline TW & $\leftrightarrow$ & TMC & 0.643 \\
\hline$P R$ & $\leftrightarrow$ & TMC & 0.471 \\
\hline CS & $\leftrightarrow$ & $\mathrm{El}$ & 0.519 \\
\hline TW & $\leftrightarrow$ & $\mathrm{El}$ & 0.563 \\
\hline $\mathrm{El}$ & $\leftrightarrow$ & $P R$ & 0.564 \\
\hline $\mathrm{El}$ & $\leftrightarrow$ & $\mathrm{Cl}$ & 0.577 \\
\hline CS & $\leftrightarrow$ & TW & 0.621 \\
\hline $\mathrm{CS}$ & $\leftrightarrow$ & PR & 0.466 \\
\hline CS & $\leftrightarrow$ & $\mathrm{Cl}$ & 0.568 \\
\hline TW & $\leftrightarrow$ & $P R$ & 0.379 \\
\hline TW & $\leftrightarrow$ & $\mathrm{Cl}$ & 0.518 \\
\hline $\mathrm{Cl}$ & $\leftrightarrow$ & PR & 0.907 \\
\hline
\end{tabular}

Table 11. Regression weight

Source: Researchers.

\begin{tabular}{|c|c|c|c|c|c|c|}
\hline \multicolumn{3}{|c|}{ Path coefficients } & \multirow{2}{*}{$\frac{\text { Estimate }}{0.201}$} & \multirow{2}{*}{$\frac{\text { S.E. }}{0.034}$} & \multirow{2}{*}{$\begin{array}{r}\text { C.R. } \\
5.922\end{array}$} & \multirow{2}{*}{$\frac{\mathbf{P}}{* * *}$} \\
\hline SQ & $\leftarrow$ & $\mathrm{CS}$ & & & & \\
\hline SQ & $\leftarrow$ & TW & -0.005 & 0.032 & -0.161 & 0.872 \\
\hline SQ & $\leftarrow$ & $\mathrm{El}$ & 0.226 & 0.027 & 8.525 & $* * *$ \\
\hline SQ & $\leftarrow$ & $\mathrm{Cl}$ & 0.253 & 0.061 & 4.158 & $* * *$ \\
\hline SQ & $\leftarrow$ & PR & -0.104 & 0.051 & -2.029 & 0.042 \\
\hline SQ & $\leftarrow$ & TMC & 0.477 & 0.03 & 15.832 & $* * *$ \\
\hline
\end{tabular}

Note: $* * *$ - significantly different from zero at the 0.001 level (two-tailed).
Table 12. Squared multiple correlations

Source: Researchers

\begin{tabular}{c|c}
\hline Variable & Estimate \\
\hline SQ & 0.95 \\
\hline
\end{tabular}

Table 13. Standardized Regression Weights

Source: Researchers

\begin{tabular}{|c|c|c|c|}
\hline \multicolumn{3}{|c|}{ Path coefficients } & \multirow{2}{*}{$\begin{array}{c}\text { Estimate } \\
.189\end{array}$} \\
\hline SQ & $\leftarrow$ & CS & \\
\hline SQ & $\leftarrow$ & TW & -.005 \\
\hline SQ & $\leftarrow$ & $\mathrm{EI}$ & .277 \\
\hline SQ & $\leftarrow$ & $\mathrm{Cl}$ & .252 \\
\hline$S Q$ & $\leftarrow$ & PR & -.115 \\
\hline $\mathrm{SQ}$ & $\leftarrow$ & TMC & .536 \\
\hline
\end{tabular}

\subsection{The first hypothesis}

H01: TQM factors do not directly relate to each other in the private healthcare sector in North West Bank Palestine.

Ha1: TQM factors directly relate to each other in the private healthcare sector in North West Bank Palestine.

The researchers used Table 9 to test the first hypothesis. Table 9 reveals that TQM factors are positively and directly related to each other in the Palestinian private healthcare sector in the Northern Area of West Bank, the calculated $p$-value per each factor was $<0.05$; it means that the researchers will accept the alternative hypothesis, which indicates that TQM factors are directly related to each other in private healthcare sector for the mentioned geographic area.

Table 10 presents the correlations between the TQM factors. The results show a significant positive relationship between all the TQM factors. The highest correlations exist between CI and PR, where $R=0.907, p<0.01$, as well as between CS and TW $(R=0.621, p<0.01)$. Moreover, TMC is highly associated with three TQM factors (TW, EI, and CS) $(R=0.643, p<0.01 ; R=0.635, p<0.01 ; R$ $=0.609, p<0.01)$, respectively.

\subsection{The second hypothesis}

H02: TQM factors do not influence service quality in the private healthcare sector in North West Bank Palestine. 
Ha2: TQM factors influence service quality in the private healthcare sector in North West Bank Palestine.

The results in Tables 11 and 12 indicate a direct and positive relationship between SQ and four factors of TQM (CS, EI, CI, and TMC) and a negative direct relationship between PR and SQ. Based on the results in Table 11, the $p$-value for these five TQM factors is less than 0.05 , which means there is a significant relationship between the independent and the dependent variable. The researchers will accept the alternative hypothesis, which indicates an influence of TQM factors on SQ. The next step in this analysis is to assess the influence of four factors on SQ.

Five significant TQM factors contribute to predicting SQ in the private healthcare services sector in North West Bank Palestine based on the results in Table 12; $R^{2}=0.950$, which means TQM factors explain $95 \%$ from the SQ variation.

Through the SEM model, the researchers need to prove the influence for five TQM factors on service quality; these predictors (CS, EI, CI, PR, and TMC) $\beta=.201, p=0.000, \beta=.226, p=0.000$, $\beta=.253, p=0.000, \beta=-0.104, p=0.042, \beta=.477$, $p=0.000$, respectively, construct the econometric model equation that expresses the influence of each factor on SQ.

The study econometric model equation is as follows:

$S Q=0.201 C S+0.226 E I+$

$+0.253 C I-0.104 P R+0.477$ TMC.

(1) Based on these results, it is clear that these three pillars (continual improvements, teamwork, and top management commitment) construct the most effective TQM system in the private health sector. The private healthcare organizations and centers need to focus and pay more attention to the best implementation of these pillars inside their places. It will reflect the best practices in applying such TQM in these places, which equip and give them better competitive advantage among other competitors. Besides, the continual improvements in the organization revealed that it must be aligned and connected with the organizational processes to achieve higher quality of the provided services for the customers, whereas top management commitment is the organization's backbone to monitor 
the teamwork, employee involvement, and the degree of customer satisfaction.

It indicates that top management commitment is the most significant factor affecting the service quality in the healthcare sector. Decision makers need to stress and instill the value of the top management commitment in enhancing the quality of the healthcare sector. Besides, this factor is one of the most important pillars in applying an effective TQM system in healthcare sector.

\subsection{The second hypothesis}

It was a surprising result that shows that TQM factors highly predict the variance in the service quality $(95 \%)$ of private healthcare services in Palestine. The researchers' results in Hypothesis 2 show a significant influence of TQM factors on service quality. TQM factors significantly predict service quality. The results show that the only TQM factor, which is teamwork, does not contribute to predicting service quality.

\section{CONCLUSION}

This study aims to clearly address the role of TQM factors on the quality of private healthcare services in Palestine. The findings indicate a significant positive relationship between the private healthcare service quality and TQM. TQM factors (customer satisfaction, employee involvement, continual improvement, processes, and top management commitment) predict $95 \%$ of the variation in the service quality of the private healthcare services in Palestine. The findings show that the continual improvements by these private healthcare organizations and centers are the key to successfully adopt and implement an effective TQM system inside their organizations and centers. Top management commitment is the main factor among all six factors of TQM, which is highly responsible in influencing the service quality of healthcare services in Palestine from the employees' point of view; decision-makers are responsible to follow up and keep the continual improvements of these centers. The notable issue was the high direct relationship between the continual improvements and processes. It was the highest influence among two factors in TQM. The other notable point is processes that influence service quality negatively, so processes must be aligned with continual improvements in a way that facilitates the work functions in the targeted organizations. Besides, the complex processes that add more bureaucratic practices in the work will influence the Service quality negatively.

\section{RECOMMENDATIONS}

The author advised the top management of these private healthcare organizations and centers to pay most of the efforts, resources, and competencies to keep improving their services that are aligned with the patients' needs and expectations, and to avoid the monotonic processes that affect the quality of their services negatively. Top management needs to be committed with their improvements decisions and to keep an eye in achieving these decisions and how it will be reflected on the ground, and its role in improving the overall private healthcare service quality in Palestine. There is a high competition among these different private healthcare organizations and centers in obtaining the most qualified competencies and the cutting-edge technologies to improve their services. So, it is highly recommended to engage and involve the front office level of employees to participate in the decision-making process in their organizations and centers as a strategic plan. Organizations need to adopt the bottom-up approach from the researcher's point of view, as it is the most successful strategy in Palestine for most of the service-based sectors. Furthermore, top management is required to adopt more managerial practices to enhance the Teamwork performance and efficiency to achieve a higher level of service quality.

The significance of this study in highlighting the gap in the private healthcare sectors in terms of the factors that influence their centers' service quality. The researchers found two critical issues that need more investigations; the first one which is the teamwork, as mentioned earlier in the results. Teamwork 
was not among the predictors that predict the private healthcare service quality, while it has a strong relationship and high influence in TQM application. The second issue, which is the significant negative role of processes in the private healthcare service quality, needs more investigation to classify types of processes that influence the quality of service for these healthcare centers positively and negatively. Besides, processes and continual improvements are highly associated with each other; it merits discovering the relationship between these two factors of TQM.

\section{REFERENCES}

1. Abdullah, S. (2018). Skills Shortages and Gaps in the Health Sector in the Occupied Palestinian Territory. The Palestine Economic Policy Research Institute (MAS). Retrieved from https://www.mas.ps/files/ server/20181907102733-1.pdf

2. Al-Adham, M. (2004). Assessment of Perceived Health Care Service Quality at Palestinian Hospitals: A Model for Good Hospital Management Practice (GHMP) (Master's Thesis). An-Najah University, Nablus-Palestine. Retrieved from https://pdfs.semanticscholar.org/11d1/3f456ee3439927 9c4d2ea185294f1af660fd.pdf

3. Al-Ali, M. A. (2014). Developing a Total Quality Management Framework for Healthcare Organizations. Proceedings of the 2014 International Conference on Industrial Engineering and Operations Management. Bali, Indonesia. Retrieved from https:// www.semanticscholar.org/paper/ Developing-a-Total-Quality-Management-Framework-for-Al-Ali/56 fc8bc0b27f55c95873f853b3596750 eb3ccad4

4. Al-Omar, B. (2002). The extent to which TQM principles are implemented in Riyadh city hospitals: from the perspectives of nurses. Journal of Public Administration, 24(2), 307-352.

5. Al-Refaie, A., Ghnaimat, O., \& Ko, J.-H. (2011). The effects of quality management practices on customer satisfaction and innovation: A perspective from Jordan. International Journal of Productivity and Quality Management, 8(4), 398-415. https://dx.doi.org/10.1504/ IJPQM.2011.043007

6. Al-Shdaifat, E. A. (2015). Implementation of total quality management in hospitals. Journal of Taibah University Medical Sciences, 10(4), 461-466. Retrieved from https://core.ac.uk/download/ pdf/82194308.pdf

7. Awuor, E., \& Kinuthia, D. (2013). Total Quality Management Practices in Selected Private Hospitals in Nairobi, Kenya. European Journal of Business and Management, 5(13), 33-44. Retrieved from https://core. ac.uk/download/pdf/45380846.pdf

8. Bagozzi, R. P., Yi, Y., \& Phillips, L. W. (1991). Assessing Construct Validity in Organizational Research. Administrative Science Quarterly, 36(3), 421-458. Retrieved from https://www.jstor.org/stable/2393203

9. Behara, R., Fisher, W., \& Lemmink, J. (2016). Modelling and Evaluating Quality Measurement using Neural Networks. International Journal of Operations \& Production Management 22(10), 1162-1185. https://doi. org/10.1108/01443570210446360

10. Brysland, A., \& Curry, A. (2015). Service Improvements in public services using SERVQUAL. Managing Service Quality, 11(6), 389-401. https://doi. org/10.1108/09604520110410601

11. Chin, W. W. (1998). Commentary: Issues and Opinion on Structural Equation Modeling. MIS Quarterly, 22(1), 7-16. Retrieved from https:// www.jstor.org/stable/249674?seq=1

12. Dagger, T. S., Sweeney, J. C., \& Johnson, L. W. (2007). A Hierarchical Model of Healthcare service quality. Scale Development and Investigation of an Integrated Model. Journal of Service Research, 10(2), 123-142.

13. Davies, E. (2003). Quality: its historical context. Engineering Management, 13(2), 14-17. http:// dx.doi.org/10.1049/em:20030212
14. Gorji, M. (2017). The Study of the Relationship between Total Quality Management and Service Quality Improvement Leading to an Optimal Model Presentation. Australian Journal of Basic and Applied Sciences, 5(11), 17421749. Retrieved from https://pdfs. semanticscholar.org/07f5/9089a95 09fb38a120c70bcbb670e8148f371. pdf?_ga $=2.64635627 .592547560 .1$ 586438976-2100778558.1584432533

15. Halis, Mi., Twati, M. R., \& Halis, Mu. (2017). Total quality management implementation in the healthcare industry: Findings from Libya. Management Issues in Healthcare System, 3(1), 4-21. http://dx.doi. org/10.33844/mihs.2017.60466

16. Health Evidence Network (HEN). (2003). What are the best strategies for ensuring quality in hospitals? (Report). Retrieved from http:// www.euro.who.int/_data/assets/ pdf_file/0006/74706/E82995.pdf

17. James, B. (2017). Quality Management aor Health Care Delivery. Chicago, Illinois: The Hospital Research and Educational Trust. Retrieved from https://www. ghdonline.org/uploads/QMMP.pdf

18. Lim, J.-S., Lim, K.-S., Heinrichs, J. H., Al-Aali, K., Aamir, A., \& Qureshi, M. I. (2018). The role of hospital service quality in developing the satisfaction of the patients and hospital performance. Management Science Letters, 8(12), 1353-1362. Retrieved from http:// www.growingscience.com/msl/ Vol8/msl_2018_98.pdf

19. Marshall, G., \& Murdoch, I. (2001) Service quality in consulting marketing engineers. International Journal Construction Marketing, 3(1), 41-49.

20. Masrurul, M. (2018). Impact of Service Quality on Customer 
Satisfaction in Bangladesh Tourism Industry: An Empirical Study. Advances in Management, 12(1), 136-140. Retrieved from https:// worldresearchersassociations.com/ mngmntspecialissue/23.pdf

21. Milakovich, M. E. (1991). Total Quality Management in the Public Sector. National Productivity Review, 10(2), 195-213. https://doi. org/10.1002/npr.4040100208

22. MOH. (2019). Annual Health Report, Palestine 2018. Retrieved from http://healthclusteropt.org/admin/file_manager/uploads/files/1/ Health\%20Annual\%20Report\%20 Palestine\%202018.pdf

23. Nabitz, U. W., \& Walburg, J. A. (2000). Addicted to qualitywinning the Dutch Quality Award based on the EFQM Model. International Journal of Health Care Quality Assurance, 13(6-7), 259-265. https://doi. org/10.1108/09526860010373235

24. Narallah, T. (2009). Measurement of Total Quality Management Critical Success Factors Implementation Level in the Palestinian Healthcare Sector (Master's Thesis). BIRZEIT University-Palestine. Retrieved form https://fada.birzeit.edu/ bitstream/20.500.11889/1273/1/ thesis_20.pdf

25. Nasser, M., Khraim, I., \& Mousa, A.-B. (2016). Measuring the Implementation of TQM Concepts in Northern West Bank Governmental Hospitals. Retrieved from https:// eng-old.najah.edu/ar/graduationprojects/8232

26. Neetha, K., Srinivas, T. R., Ramachandra, C. G., \& Manjunatha, B. (2016). A Study on Implementation of Total Quality Management (TQM) in Hospital to Improve Service Quality. Proceeding of National Conference on Advances in Mechanical Engineering Science. Retrieved from http://www. ijettjournal.org/Special\%20issue/ NCAMES-2016/NCAMES-106.pdf

27. Nzioka, P. N., \& Njuguna, R. (2017). Firm Orientations and Performance of Hotels in Nairobi County, Kenya. Journal of Business and Strategic Management, 2(3), 1-28. Retrieved from http://business.ku.ac.ke/ images/141-734-1-PB_2017.pdf
28. Ozdal, M. A., \& Oyebamiji, B. F. (2018). Implementation of Total Quality Management and its Effect on Employees' Performance in a Teaching Hospital in Oyo State, Nigeria. Public Health Open Access, 2(3). Retrieved from https:// medwinpublishers.com/PHOA/ PHOA16000129.pdf

29. Parasuraman, A., Zeithaml, V. A., \& Berry, L. L. (1988). SERVQUAL: A multiple-item scale for measuring consumer perceptions of service quality. Journal of Retailing, 64(1), 12-40. Retrieved from https://www.researchgate. net/publication/225083802 SERVQUAL_A_multiple-_Item_ Scale_for_measuring_consumer_ perceptions_of_service_quality

30. Patel, G. (2015). Total Quality Management in Healthcare. The MIDAS Journal. Retrieved from https://www.midasjournal.org/ browse/publication/690

31. Pekkaya, M., Imamoğlu, Ö. P., \& Koca, H. (2017). Evaluation of healthcare service quality via Servqual scale: An application on a hospital. International Journal of Healthcare Management, 12(4), 340-347. https://doi.org/10.1080/2 0479700.2017.1389474

32. Perrott, B. (2010). Strategic Implications of Quality Management in Health Care. Journal of Change Management, 3(2), 158-166. Retrieved from https://opus.lib.uts.edu.au/handle/10453/10021

33. Ramseook-Munhurrun, $\mathrm{P}$., Lukea-Bhiwajee, S. D., \& Naidoo, P. (2010). Service Quality in the Public Service. International Journal of Management and Marketing Research, 3(1), 3750. Retrieved from http://www. theibfr2.com/RePEc/ibf/ijmmre/ ijmmr-v3n1-2010/IJMMRV3N1-2010-3.pdf

34. Ramseook-Munhurrun, P., Munhurrun, V., \& Panchoo, A. (2011). Total Quality Management Adoption in a Public Hospital: Evidence from Mauritius. Global Journal of Business Research, 5(3), 67-77. Retrieved from https:// ideas.repec.org/a/ibf/gjbres/ v5y2011i3p67-77.html
35. Ruvio, A., Shoham, A., \& Brenčič M. M. (2008). Consumers' Need for Uniqueness: Short-Form Scale Development and Cross-Cultural Validation. International Marketing Review, 25(1), 33-53. https://doi. org/10.1108/02651330810851872

36. Scholtes, P. R. (2015). The Team Handbook: How to Use Teams to Improve Quality. Madison: Joiner Associates, Inc.

37. Sofijanova, E., \& Zabijakin-Chatleska, V. (2013). Employee Involvement and Organizational Performance: Evidence from the manufacturing sector in the Republic of Macedonia. Trakia Journal of Sciences, 11(1), 31-36. Retrieved from http://eprints.ugd. edu.mk/8225/1/Trakia\%20Journal $\% 20$ of $\% 20$ Sciences $\% 28$ moj $\% 20$ tekst\%29.pdf

38. Talib, F., Rahman, Z., \& Azam, M. (2010). Total Quality Management Implementation in the Healthcare Industry: A Proposed Framework. In 2nd International Conference on Production and Industrial Engineering (CPIE-2010) (pp. 1361-1368). Retrieved from https://www.researchgate.net/ publication/292592303_Total_quality_management_implementation_ in_the_healthcare_industry_a_proposed_framework

39. Taylor, W., \& Wright, T. (2017) The impact of senior managers commitment on the success of TQM programs: An empirical study. International Journal of Manpower, 24(5), 535-550. https://doi. org/10.1108/01437720310491071

40. Travakol, M., \& Dennick, R. (2011) Making Sense of Cronbach's alpha. International Journal of Medical Education, 2, 53-55. https://dx.doi. org/10.5116/ijme.4dfb.8dfd

41. World Health Organization (WHO). (2004). Quality improvement in primary health care: a practical guide. Retrieved from http://applications. emro.who.int/dsaf/dsa231.pdf

42. Zarei, E., Daneshkohan, A., Khabiri, R., \& Arab, M. (2015). The Effect of Hospital Service Quality on Patient's Trust. Iranian Red Crescent Medical Journal, 17(1), e17505. https://dx.doi. org/10.5812\%2Fircmj.17505 